\title{
REVIEW ARTICLE Animal leptospirosis in small tropical areas
}

\author{
A. DESVARS ${ }^{1 *}$, E. CARDINALE ${ }^{1}$ AND A. MICHAULT ${ }^{2}$ \\ ${ }^{1}$ Centre Régional de Recherche et de Veille sur les Maladies Emergentes de l'Océan Indien (CRVOI), \\ Sainte-Clotilde, La Réunion \\ ${ }^{2}$ Service de Bactériologie Parasitologie Virologie et Hygiène, Groupe Hospitalier Sud Réunion (GHSR), \\ Saint Pierre, La Réunion
}

(Accepted 10 August 2010; first published online 28 September 2010)

\section{SUMMARY}

Leptospirosis is the most widespread zoonosis in the world. Humans become infected through contact with the urine of carrier animals, directly or via contaminated environments. This review reports available data on animal leptospirosis in ten tropical islands: Barbados, Martinique, Guadeloupe, Grenada, Trinidad, New Caledonia, Hawaii, French Polynesia, La Réunion and Mayotte. Leptospirosis is endemic in these insular wild and domestic fauna. Each island presents a specific panel of circulating serovars, closely linked with animal and environmental biodiversity, making it epidemiologically different from the mainland. Rats, mongooses and mice are proven major renal carriers of leptospires in these areas but dogs also constitute a significant potential reservoir. In some islands seroprevalence of leptospirosis in animals evolves with time, inducing changes in the epidemiology of the human disease. Consequently more investigations on animal leptospirosis in these ecosystems and use of molecular tools are essential for prevention and control of the human disease.

Key words: Animal, epidemiology, island, leptospirosis, serovar, tropical.

\section{INTRODUCTION}

Leptospirosis is the most widespread zoonosis in the world but incidence of this disease is higher in tropical areas than in temperate countries [1]. Leptospires are bacteria belonging to the family Leptospiraceae, order Spirochaetales. These spirochetes are about $0 \cdot 1 \mu \mathrm{m}$ in diameter and 6-20 $\mu \mathrm{m}$ in length [2]. The genus Leptospira includes saprophytic (L. biflexa sensu lato) and pathogenic (L. interrogans sensu lato) bacteria [3] and the serological classification allows discrimination between more than 260 serovars of

\footnotetext{
* Author for correspondence: Miss A. Desvars, CIRAD Pôle Elevage, Station Ligne Paradis, 7 chemin Irat, 97410 Saint-Pierre, La Réunion.

(Email: amelie.desvars@cirad.fr)
}

L. interrogans. Serovars that are antigenically related are grouped into serogroups but this classification is now challenged by a taxonomically more relevant genomic classification which distinguishes 13 pathogenic genomospecies [4]. Human infection most often occurs when mucous membranes or abraded skin are exposed to infected animal urine, contaminated water or soil, or infected animal tissue [2]. Many wild and domestic animals species have been identified as hosts of infecting leptospiral organisms and are able to maintain the leptospires in their kidneys and become chronic carriers, shedding the organisms in their urine [5]. Therefore, although the organism has been recovered from rats, swine, dogs, cattle, and numerous wild animals [6], micromammals (particularly rats) 
remain the main chronic renal carriers of leptospires [7-9].

We choose to present a limited number of tropical insular areas, selected according to three criteria: (i) island located in the tropics, (ii) land surface of $<20000 \mathrm{~km}^{2}$ and (iii) availability of published data on animal leptospirosis. Thus, this review deals with the following islands: Barbados, Martinique, Guadeloupe, Grenada and Trinidad in the Caribbean Sea; New Caledonia, Hawaii and French Polynesia in the Pacific Ocean; and La Réunion and Mayotte in the Indian Ocean (Table 1) [10-13]. This review presents data on leptospirosis by island and by animal species chronologically (Tables 2 and 3) [14-24]. This data-gathering can be considered as a tool for those who work on leptospirosis in tropical islands. Knowledge on the animal reservoirs of Leptospira allows a better understanding of the epidemiology of the disease in these areas and also facilitates finding practical applications for control of the disease in humans.

All the areas described are tropical islands with a land surface area $<20000 \mathrm{~km}^{2}$. In these regions the climate has two contrasting seasons: a cool and dry season and a hot rainy season. Rainfall on the islands is principally orographic (mountain caused), with the resulting annual rainfall distribution closely following the topographic contours: amounts are greatest over the upper slopes and least on the leeward coast. Geologically, except for Barbados, all these islands are totally or partially of volcanic origin. Because of their small surface area and their isolation, for a given biogeographical area, islands have less species richness per surface unit than the mainland [25]. Moreover, animal populations are often small because of the limited surface area which reduces the capacity of housing. Each tropical island has its own fauna, but all are characterized by a high density of invasive rodents of the family Muridae [26, 27], rats (Rattus sp.) or mice (Mus musculus) [22, 23, 28]. Several hunting or wild species have also been introduced by humans [20, 22, 29] and domestic animals (dogs, cats) and livestock (cattle, goats, pigs, sheep, horses) are present in all the islands [22]. Except for Trinidad, which has a huge animal biodiversity, bats (order Chiroptera) represent generally the only endemic or indigenous terrestrial mammalian species of these ecosystems. On each island only a small part of the fauna has been studied for leptospirosis (Table 2) $[15,16,18-23,30-32]$. In this review, we use the species taxonomic level in its Linnean designation. In consequence, domestic animals or wild animals born of domestic forms, have the same Latin name as the wild ancestral species [33].

Two methods are commonly used to investigate leptospirosis in animals: the microscopic agglutination test (MAT) and the culture in a specific medium. The MAT is the gold standard test and is the one most utilized for the serological diagnosis of leptospirosis [34]. It is based on the use of agglutinating specific antisera and cross-absorption with homologous antigens. Authors can give the results of the MAT at the serogroup or at the serovar level. Serogroups corresponding to the serovars cited in this paper are given in Table 4 [2]. One limitation is that serological results depend on the number of serovars included in the panel [34], but another limitation of the MAT is the difficulty in setting a threshold of positivity which can range from $1: 10$ to $1: 800$, according to the authors and the location of the study [35-39]. In contrast, in vitro culture of Leptospira from kidney, blood or urine allows the serotyping of the isolated strains with certainty [40] but this method is lengthy, of low sensitivity and notably limited by contaminants outgrowth.

\section{BARBADOS}

\section{Micromammals and mongooses}

A study conducted during 1964-1965 [41] on Rattus sp. in Barbados showed that $33 \%$ (32/98) of R. rattus and $35 \%(48 / 138)$ of $R$. norvegicus were seropositive for leptospirosis by MAT. In 1986-1987 and 1994 1995, Levett et al. [42] isolated leptospires by culture of kidneys, urine or blood from $19 \%(12 / 63)$ and $16 \%(16 / 100)$ of rats, respectively. In these studies, the prevalence of renal infection was higher in $R$. norvegicus than in $R$. rattus [41, 42], with $27 \%(37 / 138)$ and $15 \%(15 / 98)$ testing positive, respectively [41]. Isolates identified in Rattus were serovars copenhageni (serogroup Icterohaemorrhagiae), arborea (Ballum) and bim (Autumnalis). R. norvegicus carried mostly leptospires from serogroup Icterohaemorrhagiae, whereas serogroup Autumnalis was mainly found in $R$. rattus [41].

In 2002, Matthias \& Levett [21] showed that $28 \cdot 2 \%$ (24/85) of mice (Mus musculus) and 40.7\% (48/118) of mongooses (Herpestes auropunctatus) in Barbados had antibodies against Leptospira sp. In mice, the prevailing serovars assessed by serology (MAT) were arborea (Ballum) and bim (Autumnalis), whereas in mongooses the dominant serogroup was Autumnalis. 
Table 1. Presentation of the islands

\begin{tabular}{|c|c|c|c|c|c|c|c|}
\hline Island (country) & Location & $\begin{array}{l}\text { Number of islands } \\
\text { of the archipelago } \\
\text { (number inhabited) }\end{array}$ & $\begin{array}{l}\text { Main town, latitude, } \\
\text { longitude } \\
\text { (highest point) }\end{array}$ & $\begin{array}{l}\text { Total } \\
\text { terrestrial } \\
\text { surface }\end{array}$ & $\begin{array}{l}\text { Number of } \\
\text { inhabitants } \\
\text { (year of the } \\
\text { census) }\end{array}$ & $\begin{array}{l}\text { Density } \\
\text { (inhab. } / \mathrm{km}^{2} \text { ) }\end{array}$ & $\begin{array}{l}\text { Incidence of } \\
\text { human leptospirosis } \\
\text { (number of cases } \\
\text { per year per } \\
100000 \text { inhabitants)* }\end{array}$ \\
\hline $\begin{array}{l}\text { Barbados } \\
\text { (Barbados) }\end{array}$ & Caribbean Sea & $1(1)$ & $\begin{array}{l}\text { Bridgetown, } 13^{\circ} 5^{\prime} \mathrm{N}, \\
59^{\circ} 37^{\prime} \mathrm{W}(336 \mathrm{~m})\end{array}$ & $430 \mathrm{~km}^{2}$ & 281968 (2008) & 642 & $13 \cdot 3[11]$ \\
\hline $\begin{array}{l}\text { New Caledonia } \\
\text { (France) }\end{array}$ & $\begin{array}{l}\text { Southern } \\
\text { Pacific Ocean }\end{array}$ & $21(7)$ & $\begin{array}{l}\text { Nouméa, } 22^{\circ} 16^{\prime} \mathrm{S}, \\
166^{\circ} 27^{\prime} \mathrm{E}(1629 \mathrm{~m})\end{array}$ & $18575 \mathrm{~km}^{2}$ & $244410(2008)$ & $13 \cdot 16$ & $22 \cdot 85[10]$ \\
\hline Hawaii (USA) & $\begin{array}{l}\text { Northern } \\
\text { Pacific Ocean }\end{array}$ & $\begin{array}{l}122 \text { (8 main } \\
\text { islands) }\end{array}$ & $\begin{array}{l}\text { Honolulu, } 21^{\circ} 19^{\prime} \mathrm{N}, \\
157^{\circ} 50^{\prime} \mathrm{W}(4205 \mathrm{~m})\end{array}$ & $16760 \mathrm{~km}^{2}$ & $1211537(2000)$ & $42 \cdot 75$ & $\begin{array}{l}7 \cdot 9 \text { in Kauai [12] } \\
5 \cdot 9 \text { in Hawaii [12] } \\
0 \cdot 3 \text { in Oahu [12] } \\
0 \cdot 2 \text { in Maui [12] }\end{array}$ \\
\hline $\begin{array}{l}\text { French Polynesia } \\
\text { (France) }\end{array}$ & $\begin{array}{l}\text { Southern } \\
\text { Pacific Ocean }\end{array}$ & $\begin{array}{l}118 \text { (shared out } \\
\text { in } 5 \text { atolls) }\end{array}$ & $\begin{array}{l}\text { Papeete, } 17^{\circ} 32^{\prime} \mathrm{S}, \\
149^{\circ} 34^{\prime} \mathrm{W}(2241 \mathrm{~m})\end{array}$ & $4167 \mathrm{~km}^{2}$ & 259706 (2007) & 65 & $22 \cdot 69[10]$ \\
\hline $\begin{array}{l}\text { La Réunion } \\
\text { (France) }\end{array}$ & Indian Ocean & $1(1)$ & $\begin{array}{l}\text { Saint-Denis, } 20^{\circ} 52^{\prime} \mathrm{S} \\
55^{\circ} 26^{\prime} \mathrm{E}(3071 \mathrm{~m})\end{array}$ & $2512 \mathrm{~km}^{2}$ & 810000 (2009) & 313 & $5 \cdot 48[10]$ \\
\hline $\begin{array}{l}\text { Mayotte } \\
\text { (France) }\end{array}$ & $\begin{array}{l}\text { Indian Ocean } \\
\text { (Mozambique } \\
\text { Channel) }\end{array}$ & $4(2)$ & $\begin{array}{l}\text { Mamoudzou, } 12^{\circ} 46^{\prime} \mathrm{S}, \\
45^{\circ} 13^{\prime} \mathrm{E}(660 \mathrm{~m})\end{array}$ & $376 \mathrm{~km}^{2}$ & 186452 (2006) & 499 & $11 \cdot 44[10]$ \\
\hline $\begin{array}{l}\text { Martinique } \\
\text { (France) }\end{array}$ & Caribbean Sea & $1(1)$ & $\begin{array}{l}\text { Fort-de-France, } \\
14^{\circ} 36^{\prime} \mathrm{N}, 61^{\circ} 05^{\prime} \mathrm{W} \\
(1397 \mathrm{~m})\end{array}$ & $1128 \mathrm{~km}^{2}$ & 397732 (2006) & $352 \cdot 59$ & $\begin{array}{r}13 \cdot 5 \text { (Martinique }+ \\
\text { Guadeloupe) [10] }\end{array}$ \\
\hline $\begin{array}{l}\text { Guadeloupe } \\
\text { (France) }\end{array}$ & Caribbean Sea & $5(5)$ & $\begin{array}{c}\text { Basse-Terre, } 16^{\circ} 00^{\prime} \mathrm{N} \\
61^{\circ} 44^{\prime} \mathrm{W}(1467 \mathrm{~m})\end{array}$ & $1434 \mathrm{~km}^{2}$ & 400736 (2006) & 246 & \\
\hline $\begin{array}{l}\text { Grenada } \\
\text { (Grenada) }\end{array}$ & Caribbean Sea & $10(3)$ & $\begin{array}{l}\text { St-George's, } 12^{\circ} 03^{\prime} \mathrm{N}, \\
61^{\circ} 45^{\prime} \mathrm{W}(840 \mathrm{~m})\end{array}$ & $344 \mathrm{~km}^{2}$ & $110000(2005)$ & $319 \cdot 8$ & Not found \\
\hline $\begin{array}{l}\text { Trinidad } \\
\text { (Trinidad and } \\
\text { Tobago) }\end{array}$ & Caribbean Sea & $20(2)$ & $\begin{array}{l}\text { San Fernando, } \\
10^{\circ} 17^{\prime} \mathrm{N}, 61^{\circ} 28^{\prime} \mathrm{W} \\
(940 \mathrm{~m})\end{array}$ & $6768 \mathrm{~km}^{2}$ & $1262366(2000)$ & 246 & $0 \cdot 08$ [13] \\
\hline
\end{tabular}

* Registered cases only. 
Table 2. Insular repartition of the animal cited (class, order, family, Latin name and common name) and existence of studies on leptospirosis by species and island

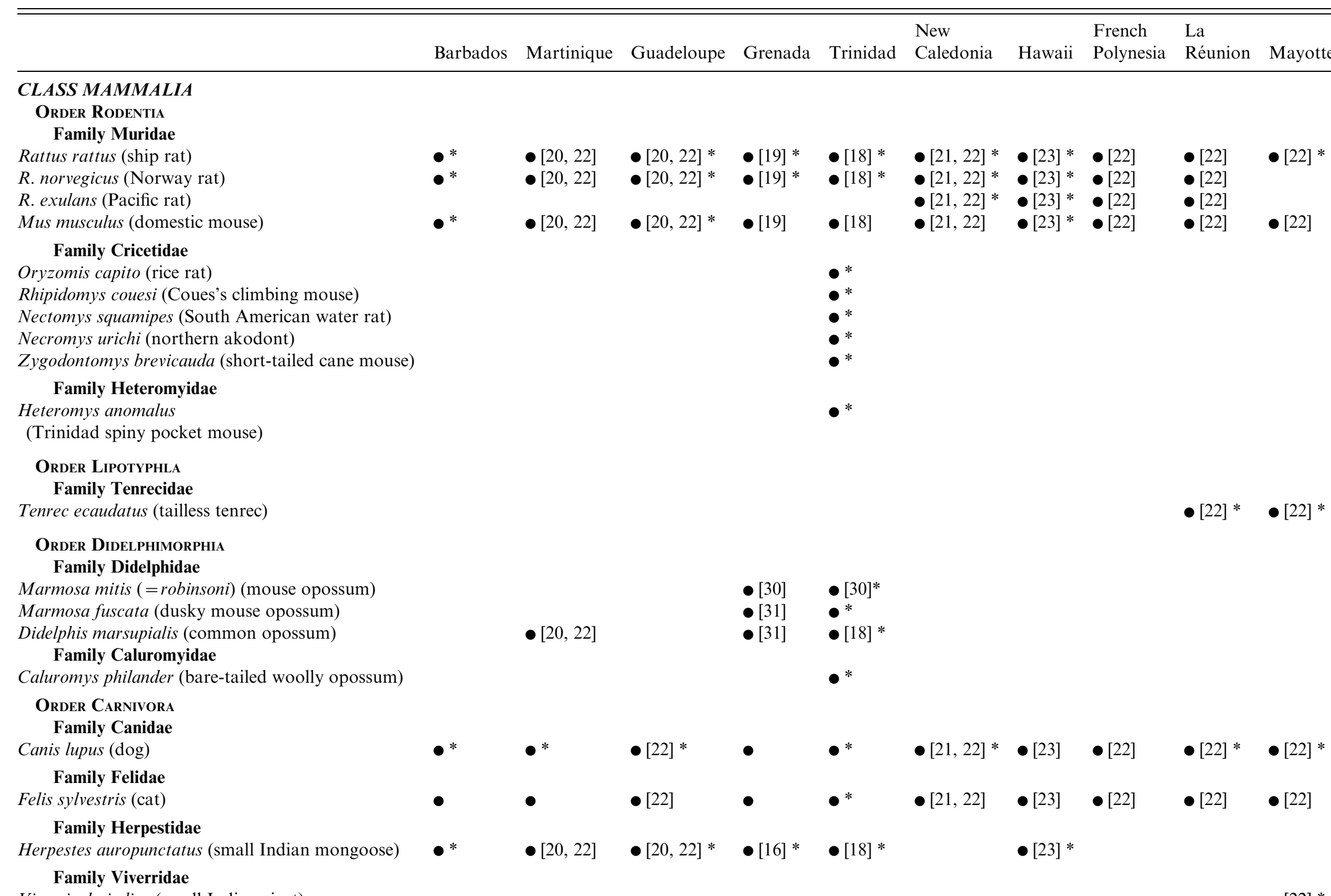


New

French

La

Barbados Martinique Guadeloupe Grenada Trinidad Caledonia Hawaii Polynesia Réunion Mayotte

Family Phocidae

Monachus schauinslandi (Hawaiian monk seal)

Order Artiodactyla

Family Bovidae

Bos primigenius (cattle)

Bubalus bubalis (water buffalo)

Capra aegagrus (goat)

Ovis orientalis (sheep)

Family Suidae

Sus scrofa (pig)

Family Cervidae

Cervus timorensis (rusa deer)

Order Perissodactyla

Family Equidae

Equus ferus (horse)

Equus asinus (ass)

Order Chiroptera

Family Phyllostomidae

Anoura geoffroyi (Geoffroy's tailless bat)

Glossophaga longirostris (Miller's long-tongued bat)

Carollia perspicillata (Seba's short-tailed bat)

Phyllostomus hastanus (greater spear-nosed bat)

Family Molossidae

Molossus major

Family Mormoopidae

Pteronotus davyi (Davy's naked-backed bat)

Family Pteropodidae

Pteropus seychellensis (Seychelles flying fox)

\section{Order Primates}

Family Cercopithecidae

Cercopithecus aethiops (vervet monkey)

Family Cebidae

Cebus albifrons (Trinidad white-fronted capuchin)

\begin{tabular}{|c|c|c|c|c|c|c|c|c|c|}
\hline$\bullet$ & $\bullet[22] *$ & - [22] * & •* & * * & - $[21,22]$ * & • [23] * & - [22] * & $\bullet[22]$ * & - [22] * \\
\hline •* & $\begin{array}{l}\bullet[22] \\
\bullet[22]\end{array}$ & $\begin{array}{l}\text { - }[22] \text { * } \\
\text { • }[22]\end{array}$ & •* & $\bullet$ & $\begin{array}{l}\text { - }[21,22] \\
\text { • }[21,22]\end{array}$ & $\begin{array}{l}\bullet[23] \\
\bullet[23]\end{array}$ & $\begin{array}{l}\bullet[22] \\
\bullet[22]\end{array}$ & $\begin{array}{l}\bullet[22] \\
\bullet[22]\end{array}$ & $\begin{array}{l}\text { - [22] * } \\
\text { - }[22]\end{array}$ \\
\hline$\bullet$ & - [22] * & - [22] * & •* & •* & $\begin{array}{l}\text { - }[21,22]^{*} \\
\text { - }[21,22]^{*}\end{array}$ & $\bullet$ - [23] & $\bullet[22] *$ & $\begin{array}{l}\text { - [22] * } \\
\text { • [22] }\end{array}$ & • [22] \\
\hline$\bullet$ & $\bullet[22]$ & • [22] * & $\bullet$ & $\begin{array}{l}\text { •* } \\
\text { •* }\end{array}$ & $\begin{array}{l}\bullet[21,22] \text { * } \\
\bullet *\end{array}$ & • [23] & - [22] * & $\begin{array}{l}\text { - [22] * } \\
\text { • [ [22] }\end{array}$ & • [22] \\
\hline
\end{tabular}

*

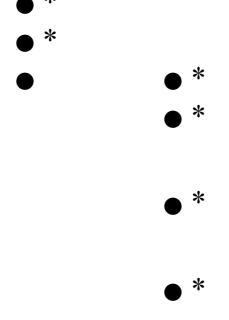

- [15] 


\begin{tabular}{|c|c|c|c|c|c|c|c|c|c|c|}
\hline & Barbados & Martinique & Guadeloupe & Grenada & Trinidad & $\begin{array}{l}\text { New } \\
\text { Caledonia }\end{array}$ & Hawaii & $\begin{array}{l}\text { French } \\
\text { Polynesia }\end{array}$ & $\begin{array}{l}\text { La } \\
\text { Réunion }\end{array}$ & Mayotte \\
\hline $\begin{array}{l}\text { ORDER CINGULata } \\
\text { Family Dasipodidae } \\
\text { Dasypus novemcinctus (nine-banded armadillo) }\end{array}$ & & & & • [19] & & & & & & \\
\hline $\begin{array}{l}C L A S S \text { AMPHIBIA } \\
\text { ORDER ANURA } \\
\text { Family Bufonidae }\end{array}$ & & & & & & & & & & \\
\hline Bufo marinus & $\bullet[16]^{*}$ & - [16] & - [16] & $\bullet[16]^{*}$ & $\bullet[16]^{*}$ & & $\bullet[16]$ & & & \\
\hline $\begin{array}{l}\text { Family Leptodactylidae } \\
\text { Eleutherodactylus sp. }\end{array}$ & •* & $\bullet[16]$ & - [16] & $\bullet[16]$ & & & • [16] & & & \\
\hline $\begin{array}{l}\text { Family Hylidae } \\
\text { Hyla minuta (lesser tree frog) }\end{array}$ & & & & & •* & & & & & \\
\hline $\begin{array}{c}\text { CLASS REPTILIA } \\
\text { ORDER SQUAMATA } \\
\text { Family Teiidae }\end{array}$ & & & & & & & & & & \\
\hline $\begin{array}{l}\text { Tupinambis nigropunctatus (gold tegu) } \\
\text { Ameiva ameiva (giant ameiva) }\end{array}$ & & & & - [32] & $\begin{array}{l}\bullet * \\
\bullet *\end{array}$ & & & & & \\
\hline $\begin{array}{l}\text { Family Iguanidae } \\
\text { Iguana iguana (common green iguana) }\end{array}$ & & & • [31] & $\bullet[31]$ & •* & & & & & \\
\hline $\begin{array}{l}\text { CLASS AVES } \\
\text { ORDER GALLIFORMES } \\
\text { Family Phasianidae } \\
\text { Gallus gallus (fowl) }\end{array}$ & & & & & & & & & & \\
\hline $\begin{array}{l}\text { Gallus gallus (fowl) } \\
\text { OrDER FALCONIFORMES } \\
\text { Family Cathartidae } \\
\text { Coragyps astratus (black vulture) }\end{array}$ & $\bullet$ & $\bullet$ & $\bullet$ & $\bullet *$ & $\bullet *$ & $\bullet$ & • & - & - & - \\
\hline
\end{tabular}

- Presence of the species on the island.

* Presence of data on leptospirosis for this species in the island concerned. 


\section{Primates}

A survey conducted on a wild population of vervet monkeys Chlorocebus (Cercopithecus) aethiops revealed a seroprevalence to Leptospira of $29.9 \%$ (150/ 501). Serogroups identified were Ballum (61\%), Icterohaemorrhagiae (16\%), Autumnalis (15\%), Pyrogenes, Panama, Pomona and Canicola $(8 \%$ combined) [43].

\section{Amphibians}

Everard \& Gravekamp [44-46] showed that amphibians were carriers of leptospires and two pathogenic strains were grown from kidneys of toads Bufo marinus (family Bufonidae) and frogs Eleutherodactylus johnstonei (family Leptodactylidae). The most prevalent strain in amphibians was L. noguchii serovar bajan (Australis) $[45,46]$, followed by serovar bim (Autumnalis) [44-46].

\section{Domestic carnivores}

A serological survey showed that $62 \%(48 / 78)$ of asymptomatic (stray or domestic) dogs had a positive MAT titre, with the dominant serogroup being Autumnalis (45\%), followed by serogroups Icterohaemorrhagiae and Australis (16\% each), then Pomona (13\%). However, in dogs presenting clinical signs of leptospirosis, the prevailing serogroup was Icterohaemorrhagiae [47]. In this study, Leptospira grown from dogs' kidneys were principally serovars copenhageni (Icterohaemorrhagiae) and bim (Autumnalis) [47, 48].

\section{Livestock}

Levett et al. [49] showed that $4 \cdot 3 \%$ of sheep (1/23) and $9 \cdot 3 \%$ of goats $(4 / 43)$ were seropositive for leptospirosis and antibodies against serogroup Cynopteri were identified in both species [49].

\section{MARTINIQUE}

\section{Domestic carnivores}

A serosurvey conducted in Martinique on dogs showed that the seroprevalence against leptospires was $76 \%(219 / 288)$ [50].

\section{Livestock}

Levett et al. [49] showed that $25 \cdot 7 \%(45 / 175)$ of cattle were seropositive for leptospirosis and that Sejroe was the most prevalent serogroup $(44.4 \%$ of the positives), followed by Icterohaemorrhagiae $(24.4 \%)$ and Autumnalis (17.7\%) [49]. In pigs, the seroprevalence was $39 \%(110 / 282)$, with a predominance of serogroups Icterohaemorrhagiae and Sejroe, followed by Australis and Cynopteri [50].

\section{GUADELOUPE}

\section{Micromammals and wild carnivores (mongooses and racoons)}

Michel [51] observed the renal carriage of the bacteria Leptospira in $16.6 \%(2 / 12), 36.8 \%(14 / 38)$ and $57 \cdot 1 \%(8 / 14)$ of $R$. norvegicus, $R$. rattus and mice, respectively. MAT tests showed that seroprevalences in the racoon and the mongoose were similar with $48 \%(354 / 737)$ and $47 \%(8 / 17)$ positive, respectively $[51,52]$. The serovar arborea (Ballum) was predominantly found in kidneys of mice [51], while serogroup Icterohaemorrhagiae was isolated from $R$. rattus, and serogroups Icterohaemorrhagiae, Sejroe and Australis were isolated from mongooses [51, 52].

\section{Domestic carnivores}

A recent MAT survey showed that $78 \cdot 3 \%(83 / 106)$ of the Guadelupian dogs were seropositive against Leptospira [50].

\section{Livestock}

In 1973-1974, the dominant serogroup in cattle in Guadeloupe was Ballum (prevalence not shown) and the other serogroups found in cattle were Icterohaemorrhagiae, Bataviae, Australis, Pomona, and Sejroe [53]. A serosurvey in 2002-2003 showed that $14 \%(29 / 205)$ of cattle were serologically positive against Leptospira [50].

Levett et al. [49] showed that $6 \cdot 4 \%(13 / 203)$ of goats were seropositive for leptospirosis and Autumnalis, Cynopteri and Sejroe were identified as the infecting serogroups [49].

A serological study in 27 pig farms in the 1990s in Guadeloupe showed that $93 \%$ of swine were positive [54] but this seroprevalence fell to $35 \%(141 / 403)$ in 2002-2003 [50].

\section{Equines}

In $2002-2003,61 \%(74 / 121)$ of horses were serologically positive against Leptospira [50]. 
Table 3. Main animal species studied for leptospirosis in the considered islands and results

\begin{tabular}{|c|c|c|c|c|c|c|c|c|c|c|}
\hline & Barbados & Martinique & Guadeloupe & Grenada & Trinidad & $\begin{array}{l}\text { New } \\
\text { Caledonia }\end{array}$ & Hawaii & $\begin{array}{l}\text { French } \\
\text { Polynesia }\end{array}$ & $\begin{array}{l}\text { La } \\
\text { Réunion }\end{array}$ & Mayotte \\
\hline \multicolumn{11}{|l|}{ Rattus rattus } \\
\hline Seropositive & $33 \%(32 / 98)$ & ND & $\begin{array}{l}36 \cdot 8 \% \\
(14 / 38)\end{array}$ & ND & $16 \%(5 / 32)$ & ND & $\begin{array}{l}19.7 \% \\
(72 /\end{array}$ & ND & ND & $0 \%(0 / 19)$ \\
\hline $\begin{array}{l}\text { Main } \\
\text { serogroups } \\
\text { found by } \\
\text { MAT }\end{array}$ & ND & & ND & ND & $\begin{array}{l}\text { Ictero. } \\
\text { Autumnalis } \\
\text { Hebdomadi } \\
\text { Javanica }\end{array}$ & ND & $366)$ & & & / \\
\hline Renal carriers & $15 \%(15 / 98)$ & & ND & ND & ND & $\begin{array}{l}61 \cdot 1 \%(11 / 18) \\
(R . \text { rattus, } \\
R . \text { norvegicus, } \\
\text { R. exulans })\end{array}$ & $\begin{array}{c}43 \cdot 7 \% \\
(160 / \\
366)\end{array}$ & & & ND \\
\hline $\begin{array}{l}\text { Serogroups } \\
\text { isolated from } \\
\text { kidney }\end{array}$ & $\begin{array}{l}\text { Ictero. } \\
\text { Ballum } \\
\text { Autumnalis }\end{array}$ & & Ictero. & $\begin{array}{l}\text { Ictero. } \\
\text { Ballum }\end{array}$ & $\begin{array}{l}\text { Ictero. } \\
\text { Ballum } \\
\text { Louisiana }\end{array}$ & $\begin{array}{l}\text { Ictero. } \\
\text { Canicola }\end{array}$ & $\begin{array}{l}\text { Ictero. } \\
\text { Ballum }\end{array}$ & & & ND \\
\hline \multicolumn{11}{|c|}{ Rattus norvegicus } \\
\hline Seropositive & $\begin{array}{l}35 \% \\
(48 / 138)\end{array}$ & ND & $\begin{array}{r}16 \cdot 6 \% \\
(2 / 12)\end{array}$ & ND & $43 \%(3 / 7)$ & See $R$. rattus & $\begin{array}{c}32 \cdot 4 \% \\
(165 /\end{array}$ & ND & ND & Absent \\
\hline $\begin{array}{l}\text { Main } \\
\text { serogroups } \\
\text { found by } \\
\text { MAT }\end{array}$ & ND & & ND & ND & $\begin{array}{l}\text { Ictero. } \\
\text { Autumnalis } \\
\text { Hebdomadi } \\
\text { Javanica }\end{array}$ & & $510)$ & & & \\
\hline Renal carriers & $\begin{array}{l}27 \% \\
(37 / 138)\end{array}$ & & ND & ND & ND & & $\begin{array}{l}60 \cdot 2 \% \\
(307 / 510)\end{array}$ & & & \\
\hline $\begin{array}{l}\text { Serogroups } \\
\text { isolated from } \\
\text { kidney }\end{array}$ & $\begin{array}{l}\text { Ictero. } \\
\text { Ballum } \\
\text { Autumnalis }\end{array}$ & & ND & Ictero. & Ictero. & & $\begin{array}{l}\text { Ictero. } \\
\text { Ballum } \\
\text { Australis }\end{array}$ & & & \\
\hline \multicolumn{11}{|l|}{ Mus musculus } \\
\hline Seropositive & $\begin{array}{l}28 \cdot 2 \% \\
(24 / 85)\end{array}$ & ND & $\begin{array}{r}57 \cdot 1 \% \\
(8 / 14)\end{array}$ & ND & $29 \%(2 / 7)$ & ND & $\begin{array}{l}66 \cdot 7 \% \\
(26 / 39)\end{array}$ & ND & ND & ND \\
\hline $\begin{array}{l}\text { Main } \\
\text { serogroups } \\
\text { found by MAT }\end{array}$ & $\begin{array}{l}\text { Ballum } \\
\text { Autumnalis }\end{array}$ & & ND & & Ictero. & & & & & \\
\hline Renal carriers & ND & & ND & & ND & & $\begin{array}{l}79 \cdot 5 \% \\
(31 / 39)\end{array}$ & & & \\
\hline $\begin{array}{l}\text { Serogroups } \\
\text { isolated from } \\
\text { kidney }\end{array}$ & ND & & Ballum & & ND & & $\begin{array}{l}\text { Ictero. } \\
\text { Ballum }\end{array}$ & & & \\
\hline
\end{tabular}

kidney 


\begin{tabular}{|c|c|c|c|c|c|c|c|c|c|c|}
\hline & Barbados & Martinique & Guadeloupe & Grenada & Trinidad & $\begin{array}{l}\text { New } \\
\text { Caledonia }\end{array}$ & Hawaii & $\begin{array}{l}\text { French } \\
\text { Polynesia }\end{array}$ & $\begin{array}{l}\text { La } \\
\text { Réunion }\end{array}$ & Mayotte \\
\hline \multicolumn{11}{|c|}{ Herpestes auropunctatus } \\
\hline Seropositive & $\begin{array}{l}40 \cdot 7 \% \\
(48 / 118)\end{array}$ & ND & $47 \%(8 / 17)$ & $\begin{array}{c}35-36 \%(152 / \\
432-71 / 200)\end{array}$ & $48 \%(17 / 37)$ & Absent & $\begin{array}{c}28 \cdot 6 \% \\
(36 /\end{array}$ & Absent & Absent & Absent \\
\hline $\begin{array}{l}\text { Main } \\
\text { serogroups } \\
\text { found by } \\
\text { MAT }\end{array}$ & Autumnalis & & ND & $\begin{array}{l}\text { Ictero. }(37 \cdot 5 \%) \\
\text { Pomona }(21 \cdot 1 \%) \\
\text { Canicola } \\
(6 \cdot 6 \%)\end{array}$ & $\begin{array}{l}\text { Canicola } \\
\text { Ictero. } \\
\text { Pomona }\end{array}$ & & 126) & & & \\
\hline $\begin{array}{l}\text { Serogroups } \\
\text { isolated from } \\
\text { kidney }\end{array}$ & ND & & $\begin{array}{l}\text { Ictero. } \\
\text { Sejroe } \\
\text { Australis }\end{array}$ & $\begin{array}{l}\text { Ictero. } \\
\text { Bataviae } \\
\text { Tarassovi }\end{array}$ & Canicola & & $\begin{array}{l}\text { Ictero. } \\
\text { Canicola } \\
\text { Sejroe }\end{array}$ & & & \\
\hline \multicolumn{11}{|l|}{ Bos primigenius } \\
\hline Seropositive & ND & $\begin{array}{l}25 \cdot 7 \% \\
(45 / 175)\end{array}$ & $\begin{array}{l}14 \% \\
(29 / 205)\end{array}$ & $\begin{array}{l}25 \% \\
(80 / 324)\end{array}$ & $\begin{array}{l}92 \% \\
(24 / 26)\end{array}$ & $\begin{array}{l}58 \cdot 3 \% \\
(204 / 350)\end{array}$ & ND & $\begin{array}{l}15 \cdot 5 \%(23 / \\
148)(\text { dairy } \\
\text { cattle) }\end{array}$ & $\begin{array}{c}29-32 \% \\
(452 / 1582- \\
337 / 1063)\end{array}$ & $85 \%(34 / 40)$ \\
\hline Renal carriers & & ND & ND & ND & ND & ND & ND & ND & ND & ND \\
\hline $\begin{array}{l}\text { Serogroups } \\
\text { isolated from } \\
\text { kidney }\end{array}$ & & ND & ND & ND & ND & ND & ND & ND & ND & ND \\
\hline
\end{tabular}




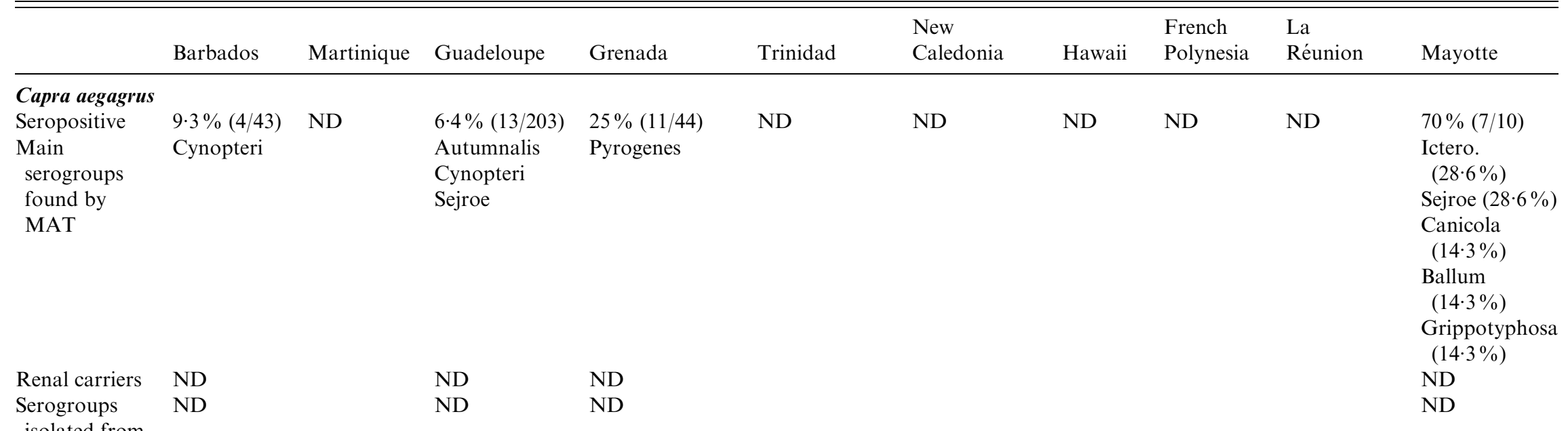

kidney

\section{Sus scrofa}

Seropositive

\section{Main}

serogroups

found by

MAT

$\begin{array}{ll}39 \% & 35 \% \\ (110 / 282) & (141 / 403)\end{array}$

Ictero. ND

Sejroe

Australis

Cynopteri

$$
\begin{aligned}
& 35 \% \\
& (45 / 130)
\end{aligned}
$$

Autumnalis

$(35 \%)$

Ictero.

(32\%)

$\begin{array}{ll}52 \% & 58 \cdot 3 \% \\ (64 / 122) & (21 / 36) \\ & \\ \begin{array}{l}\text { Ictero. }(56 \%) \\ \text { Autumnalis } \\ (29 \%)\end{array} & \begin{array}{l}\text { Pomona } \\ \text { Ictero. }\end{array}\end{array}$

$52 \%$

$(29 \%)$

$\begin{array}{lll}\text { ND } & \text { ND } & \text { ND } \\ \text { ND } & \text { ND } & \text { ND }\end{array}$

ND
ND
ND

ND

ND

$\begin{array}{ll}32-39 \% & 5 \%(3 / 57) \quad \text { ND } \\ (37 / 115- & \\ 140 / 360) & \\ \text { Ictero. } & \text { Hebdomadis } \\ (22 \cdot 6 \%) & \text { Autumnalis } \\ \text { Pomona } & \\ (18 \%) & \\ \text { Australis } & \\ (16 \cdot 7 \%) & \\ \text { Canicola } & \\ (10 \cdot 8 \%) & \\ \text { Cynopteri } & \\ (9 \cdot 9 \%) & \\ \text { Autumnalis } & \\ (7 \cdot 1 \%) & \\ \text { ND } & \text { ND } \\ \text { ND } & \text { ND }\end{array}$

kidney 


\begin{tabular}{|c|c|c|c|c|c|c|c|c|c|c|}
\hline & Barbados & Martinique & Guadeloupe & Grenada & Trinidad & $\begin{array}{l}\text { New } \\
\text { Caledonia }\end{array}$ & Hawaii & $\begin{array}{l}\text { French } \\
\text { Polynesia }\end{array}$ & $\begin{array}{l}\text { La } \\
\text { Réunion }\end{array}$ & Mayotte \\
\hline \multicolumn{11}{|l|}{ Equus ferus } \\
\hline Seropositive & ND & ND & $\begin{array}{l}61 \% \\
(74 / 121)\end{array}$ & ND & $\begin{array}{l}76 \%(66 / 87) \\
\text { (horses and } \\
\text { donkeys) }\end{array}$ & $\begin{array}{l}94 \cdot 4 \% \\
(17 / 18)\end{array}$ & ND & $\begin{array}{r}100 \% \\
(5 / 5)\end{array}$ & $\begin{array}{l}69-71 \% \\
(100 / 145- \\
121 / 171)\end{array}$ & ND \\
\hline $\begin{array}{l}\text { Main } \\
\text { serogroups } \\
\text { found by } \\
\text { MAT }\end{array}$ & & & ND & & $\begin{array}{l}\text { Panama }(23 \%) \\
\text { Ictero. }(15 \%) \\
\text { Canicola }(9 \%) \\
\text { Hebdomadis } \\
(9 \%)\end{array}$ & $\begin{array}{l}\text { Ictero. } \\
\text { Pyrogenes } \\
\text { Hurtsbridge }\end{array}$ & & $\begin{array}{l}\text { Pomona } \\
\text { Australis } \\
\text { Ictero. }\end{array}$ & $\begin{array}{l}\text { Autumnalis } \\
(30-34 \%) \\
\text { Ictero. } \\
\quad(14-18 \%) \\
\text { Australis } \\
\text { Ballum }\end{array}$ & \\
\hline Renal carriers & & & ND & & ND & ND & & ND & ND & \\
\hline $\begin{array}{l}\text { Serogroups } \\
\text { isolated from } \\
\text { kidney }\end{array}$ & & & ND & & ND & ND & & ND & ND & \\
\hline \multicolumn{11}{|l|}{ Canis lupus } \\
\hline Seropositive & $\begin{array}{l}62 \% \\
(48 / 78)\end{array}$ & $\begin{array}{l}76 \% \\
(219 / 288)\end{array}$ & $\begin{array}{l}78 \cdot 3 \% \\
(83 / 106)\end{array}$ & ND & $\begin{array}{l}55 \% \text { (stray } \\
\text { dogs) }\end{array}$ & $\begin{array}{r}59 \cdot 25 \% \\
(48 / 81)\end{array}$ & ND & ND & $\begin{array}{l}40 \%(58 / \\
142-60 / 150) \\
\text { (stray dogs) }\end{array}$ & ND \\
\hline $\begin{array}{l}\text { Main } \\
\text { serogroups } \\
\text { found by } \\
\text { MAT }\end{array}$ & $\begin{array}{l}\text { Autumnalis } \\
(45 \%) \\
\text { Ictero. } \\
(16 \%) \\
\text { Australis } \\
(16 \%) \\
\text { Pomona } \\
(13 \%)\end{array}$ & ND & ND & & $\begin{array}{l}\text { Canicola } \\
\text { Ictero. } \\
\text { Hebdomadis }\end{array}$ & $\begin{array}{l}\text { Ictero. } \\
\text { Canicola }\end{array}$ & & & $\begin{array}{l}\text { Canicola } \\
(69 \%) \\
\text { Ictero. } \\
(16-26 \%)\end{array}$ & Ictero. \\
\hline Renal carriers & & ND & ND & & $20 \%(10 / 50)$ & ND & & & ND & ND \\
\hline $\begin{array}{l}\text { Serogroups } \\
\text { isolated from } \\
\text { kidney }\end{array}$ & $\begin{array}{l}\text { Copenhageni } \\
\text { Bim }\end{array}$ & ND & ND & & $\begin{array}{l}\text { Canicola } \\
\text { Ictero. } \\
\text { Hebdomadis } \\
\text { Autumnalis } \\
\text { Ballum } \\
\text { Sejroe }\end{array}$ & ND & & & ND & ND \\
\hline
\end{tabular}

ND, No data.

Absent, Species not present on this island. 
Table 4. Relation between serovars cited in the text and serogroups (from [2])

\begin{tabular}{|c|c|}
\hline Serovars & Serogroups \\
\hline arborea, ballum & Ballum \\
\hline autumnalis, bim, bragg & Autumnalis \\
\hline $\begin{array}{l}\text { icterohaemorrhagiae, } \\
\text { copenhageni, mankarso, RGA }\end{array}$ & Icterohaemorrhagiae \\
\hline $\begin{array}{l}\text { australis, bajan, bangkok, } \\
\text { bratislava, peruviana }\end{array}$ & Australis \\
\hline sejroe, hardjo, wolffi & Sejroe \\
\hline bataviae & Bataviae \\
\hline pomona & Pomona \\
\hline tarassovi, atchafalaya, navet & Tarassovi \\
\hline canicola, portlandvere & Canicola \\
\hline cynopteri & Cynopteri \\
\hline georgia & Hebdomadis \\
\hline lanka & Louisiana \\
\hline brasiliensis & Bataviae \\
\hline grippotyphosa & Grippotyphosa \\
\hline
\end{tabular}

\section{GRENADA}

\section{Micromammals and mongooses}

Utilizing kidney culture, Everard et al. [19] showed the renal carriage of serovar copenhageni (Icterohaemorrhagiae) in R. norvegicus, while serovars copenhageni (Icterohaemorrhagiae) and ballum (Ballum) were cultured from kidneys of $R$. rattus.

In 1971-1972 and in 1983, two serosurveys showed that $35 \%(152 / 432)$ [13] to $36 \%(71 / 200)$ [19] of the Grenadian mongooses were seropositive by MAT and three serogroups were identified: Icterohaemorrhagiae was the dominant serogroup [13, 19] representing $37.5 \%(57 / 152)$ of the positives, then Pomona in $21.1 \%(32 / 152)$ of the positives and Canicola in $6 \cdot 6 \%(10 / 152)$ of the positives [13]. Leptospires were isolated from kidneys in $5 \cdot 3 \%(10 / 190)$ of the mongooses and serovars copenhageni (Icterohaemorrhagiae), brasiliensis (Bataviae) and atchafalaya (Tarassovi) were identified [19].

\section{Bats}

In bats of the family Phyllostomidae, $8 \%(4 / 52)$ of Glossophaga sp. were found positive for leptospirosis, while $21 \%(13 / 61)$ of positives were found in Anoura sp. (13/61) [19]. Of the 121 cultures of bat kidneys none gave a positive result [19].

\section{Amphibians}

Everard et al. [19] reported $15 \%$ (10/66) seropositive in the toad B. marinus. Serovars navet (Tarassovi) and peruviana (Australis) were cultured from kidneys in two of these animals.

\section{Livestock}

Everard et al. [55] found $25 \%(80 / 324)$ of cattle to be seropositive for leptospirosis and Icterohaemorrhagiae was the dominant serogroup (28\%), followed by Autumnalis $(24 \%)$ and Hebdomadis and related serogroups Sejroe and Mini (12\%) [55]. They also reported that $35 \%(45 / 130)$ of Grenadian pigs tested were seropositive, of which $35 \%$ were against serogroup Autumnalis and $32 \%$ against Icterohaemorrhagiae [55]. In sheep, $17 \%$ (18/108) were seropositive and Autumnalis was the predominant serogroup (33\% of the positive sera). In goats, seroprevalence of leptospirosis was of $25 \%(11 / 44)$ and the dominating serogroup was Pyrogenes [55].

\section{Chickens}

Everard et al. [55] reported that $11 \%(19 / 175)$ of chickens were seropositive by MAT and antibodies found were mainly against serogroups Hebdomadis ( $42 \%$ of the positives) and Shermani $(32 \%$ ).

\section{TRINIDAD}

\section{Micromammals and mongooses}

Everard et al. [19] showed that 16\% (5/32) of R. rattus were seropositive by MAT, while $43 \%$ (3/7) of $R$. norvegicus and $29 \%(2 / 7)$ of mice were seropositive. In Rattus sp. antibodies detected were directed against serogroups Icterohaemorrhagiae, Autumnalis, Hebdomadis and Javanica, while in mice, these authors found antibodies against Icterohaemorrhagiae only. Serovar copenhageni (Icterohaemorrhagiae) was isolated from the kidney of $R$. norvegicus and $R$. rattus, whereas serovars ballum (Ballum) and lanka (Louisiana) were isolated from kidneys of $R$. rattus only [19]. Everard et al. also showed that in the family Muridae, $24 \%$ (4/17) of the scaly-footed water rat Nectomys squamipes and $29 \%$ (2/7) of the rice rat Oryzomys capito were serologically positive. Twenty-five per cent (1/4) of the Trinidad spiny pocket mice Heteromys anomalus (family Heteromyidae) tested were positive. No antibodies 
against leptospires were found in Coues's climbing mouse Rhipidomys couesi (family Cricetidae) (0/2), nor the northern grass mouse Necromys urichi (family Cricetidae) $(0 / 1)$ or the cane mouse Zygodontomys brevicauda (family Muridae) (0/1) [19].

In 1976, the proportion of seropositive Trinidadian mongooses ranged between $33 \cdot 3 \%$ and $51 \cdot 1 \%$ [13], whereas in 1983, 48\% (17/37) of the mongooses sampled were seropositive [19]. In both studies, MAT results showed that serogroup Canicola predominated in this species [13, 19], but Icterohaemorrhagiae and Pomona were also encountered [13]. Canicola strains were isolated from the kidneys of mongooses $[13,19]$, with an infectivity rate of $4 \cdot 7 \%(5 / 106)[13]$.

\section{Bats}

On the eight species of bats caught by Everard et al. [19], four presented a seropositive result with the MAT method: Carollia perspicillata (family Phyllostomidae), with $11 \%$ (2/19) seropositive; Phyllostomus hastatus (family Phillostomidae), with $27 \%$ (13/48) seropositive; Pteronotus davyi (family Mormoopidae), with $13 \%$ (2/15) seropositive and Molossus major (family Molossidae) with 25\% (5/20) seropositive. Serogroups identified in bats were: Autumnalis, Hebdomadis, Javanica, Panama, Pyrogenes, Tarassovi, and Cynopteri [19].

\section{Didelphimorphia}

Everard et al. [19] showed that in the order Didelphimorphia, $5 \%(1 / 22)$ of the black-eared opossums Didelphis marsupialis (family Didelphidae) and $4 \%(5 / 73)$ of the the murine opossums Marmosa mitis ( $=$ M. robinsoni, family Didelphidae) were found seropositive. Seven per cent (1/14) of the white-eared opossums Caluromys philander (family Caluromyidae) were seropositive. Serovars lanka (Louisiana) and ballum (Ballum) were cultured from kidneys of M. mitis and serovar ballum (Ballum) was isolated from C. philander. Serological research of leptospiral antibodies was negative in Marmosa fuscata (fuscatus) but renal cultures revealed the presence of serovar lanka (Louisiana) in this species [19].

\section{Primates}

Leptospiral antibodies were researched in Cebus sp. (family Cebidae) but revealed as negative [19].

\section{Squamates and amphibians}

Forty-two per cent (5/12) of the gold tegus Tupinambis nigropunctatus (order Squamata, family Teiidae) sampled were found positive by MAT, while all the lizards Ameiva ameiva (family Teiidae) (4/4) and all the iguanas Iguana iguana (family Iguanidae) (1/1) caught were seropositive [19]. Everard et al. [19] showed that $25 \%(20 / 80)$ of the marine toads B. marinus were seropositive but none $(0 / 2)$ of the lesser tree frogs Hyla minuta (order Anura, family Hylidae) tested positive. Serovar autumnalis (Autumnalis) was isolated from the marine toad [19].

\section{Domestic carnivores}

In 1979, serological data reported that at least $55 \%$ of the stray dogs had been exposed to leptospires as opposed to only $12 \cdot 5 \%$ of the cats. Agglutinins against serogroups Canicola, Icterohaemorrhagiae and Hebdomadis were found most frequently in these species [56]. Twenty per cent $(10 / 50)$ of the sampled dogs carried leptospires in their kidneys [56]. Serovars isolated in dogs were portlandvere (Canicola), canicola (Canicola), copenhageni (Icterohaemorrhagiae) and georgia (Hebdomadis), whereas serovar canicola was isolated from one cat. A seroepidemiological survey was conducted in 2005 in different populations of Trinidadian dogs [57]: among house dogs $7 \cdot 7 \%$ $(5 / 65)$ of the non-vaccinated animals were seropositive. The prevalence was the highest among hunting dogs with $25.5 \%$ (12/47) positive, while $20 \cdot 4 \%(10 / 49)$ and $4 \cdot 4 \%(5 / 113)$ of the farm and stray dogs, respectively, were seropositive. In the population of dogs suspected of leptospirosis, $48 \%(24 / 50)$ were seropositive. Nine serovars of $L$. interrogans were identified in this species. The most prevalent serovar was mankarso (Icterohaemorrhagiae), in $47 \cdot 5 \%$ of the seropositive dogs $(29 / 61)$. The other serovars were icterohaemorrhagiae RGA (Icterohaemorrhagiae $32 \cdot 8 \%, 20 / 61$ ), autumnalis (Autumnalis $41 \%$, 25/61), copenhageni (Icterohaemorrhagiae 16.4\%, 10/61), bratislava (Australis 13.1\%, 8/61), georgia (Hebdomadis), ballum (Ballum) and wolffi (Sejroe) (1.6\% each, $1 / 61)$ [57].

\section{Livestock}

In 1985, MAT results reported that $92 \%(24 / 26)$ of cattle were seropositive with serogroup Hebdomadis predominating [55]. All of the ten 'bufflypso' (water buffaloes, Bubalus bubalis) tested were positive and 
the prevailing serogroup in these animals was Grippotyphosa [55]. In 2009, a larger study reported that $14.6 \%(33 / 226)$ of the water buffaloes were seropositive [58].

Among swine, it was shown that $52 \%(64 / 122)$ of the sampled animals were serologically positive with $56 \%$ and $29 \%$ of those seropositive having antibodies against serogroups Icterohaemorrhagiae and Autumnalis, respectively [55].

\section{Equines}

MAT results showed that $76 \%(66 / 87)$ of horses and donkeys were seropositive [55]. Panama was the most frequently reported serogroup $(23 \%$ of positive animals), followed by Icterohaemorrhagiae (15\%), Canicola and Hebdomadis (9\% each) [55].

\section{Poultry and wild birds}

Everard et al. [55] showed that $11 \%(16 / 144)$ of the chickens tested had a positive serological reaction against Leptospira. Fifty per cent of the reactions were against serogroup Shermani, while $25 \%$ were against serogroup Hebdomadis. Eight ducks and geese were also tested but were negative. No leptospiral antibodies were found in the American black vulture Coragyps atratus [55].

\section{NEW CALEDONIA}

\section{Micromammals}

In 1985-1986, a study based on culture showed that $61 \cdot 1 \%(11 / 18)$ of rats (R. rattus, $R$. norvegicus, $R$. exulans) excreted leptospires in their urine [59]. A complementary study identified the leptospires shed in urine of rats as belonging to serogroups Icterohaemorrhagiae and Canicola [60].

\section{Domestic carnivores}

In 1985-1986, Brethes et al. [60] reported that $59 \cdot 25 \%$ (48/81) of canids in New Caledonia were seropositive, of which $39.6 \%(19 / 48)$ had antibodies against serogroup Icterohaemorrhagiae. In the particular area of Bourail (a 'hot-spot' of human leptospirosis in New Caledonia), $63 \%$ (29/46) of dogs were seropositive, of which $55 \%(16 / 29)$ were against Icterohaemorrhagiae. Predominance of serogroup Icterohaemorrhagiae in canids was confirmed in 1999 by the Laboratoire Territorial de Diagnostic Vétérinaire (LTDV) whose results reported serological evidence of a high circulation of serogroup Canicola in dogs [61].

\section{Livestock}

All cattle sampled (15 animals) in the area of Bourail in 1985-1986 were positive by MAT [60]. A subsequent survey in 1990 on the entire New Caledonian cattle assessed the seroprevalence at 58.3\% (204/350), with $74.6 \%(85 / 114)$ of the surveyed herds having at least one positive animal [62]. Serogroups Sejroe, Tarassovi and Pomona were circulating in New Caledonian cattle $[60,62]$, with a prevalence of $59 \cdot 3 \%, 19 \cdot 6 \%$ and $7 \cdot 8 \%$ among the positive animals, respectively [62]. In 2007, the annual report of the LTDV confirmed the predominance of serovars hardjo (Sejroe) and sejroe (Sejroe) in cattle [10].

In 1985-1986, 58.3\% (21/36) of pigs were found to be seropositive for leptospirosis. By MAT, sera reacted principally against serogroup Pomona and secondly against Icterohaemorrhagiae [59].

Antibodies against serovar hardjo (Sejroe) were found in the Rusa deer [60].

\section{Equines}

In 1983, MAT results showed that the dominant serogroups in horses in New Caledonia were Canicola and Pomona [63]. In 1986, the dominant serogroup was Icterohaemorrhagiae: $17 / 18$ of the horses sampled in the area of Bourail were seropositive, of which nine were against Icterohaemorrhagiae [60]. Icterohaemorrhagiae was still prevailing in horses in 1996 [64]. However, since 1996, inclusion of serogroups Pyrogenes and Hurtsbridge in the MAT panel of strains demonstrated the high circulation of these serogroups in positive horses, with a frequency of $29 \cdot 3 \%$ and $18.8 \%$, respectively, in 1996 [64]; 18.7\% and $43.2 \%$, respectively, in 1998 [65]; and $52 \cdot 3 \%$ and $32 \cdot 1 \%$, respectively, in 1999 [61].

A serological survey conducted on the donkeys of Mare (Loyalty Islands) in 1999 proved that 97\% (38/39) of the sampled animals had antibodies against Leptospira. The dominant serogroups were Hurtsbridge and Pyrogenes [61].

\section{HA W A I I}

\section{Micromammals and mongooses}

In the 1950s and 1960s, the study of Wallace et al. [66] on Hawaiian rats $R$. norvegicus, $R$. rattus, $R$. hawaiiensis $(=R$. exulans), mice and mongooses 
reported that $45 \%(558 / 1238)$ of these mammals had antibodies against Leptospira. A survey conducted between 1959 and 1961 on 1281 mammals (same species as cited above) [67] showed that mice and $R$. norvegicus populations were highly infected, with respectively $66.7 \%(26 / 39)$ and $32.4 \%(165 / 510)$ seropositive by MAT and $79 \cdot 5 \%(31 / 39)$ and $60 \cdot 2 \%$ $(307 / 510)$ renal carriers. They were followed by the mongoose with $28.6 \%(36 / 126)$ seropositive, and $14 \cdot 3 \%(18 / 126)$ renal carriers. The serological prevalence in $R$. rattus was lower with $19 \cdot 7 \%(72 / 366)$ seropositive contrasting with the high rate of renal carriage $(43.7 \%, 160 / 366)$ in this species [67]. Cultures of kidney tissues proved the renal carriage of serovar icterohaemorrhagiae (Icterohaemorrhagiae) in all the species [66, 67]. Serovar ballum (Ballum) was only recovered in $R$. rattus [66]. One isolate of the serogroup Australis was obtained in $R$. norvegicus, while serogroups Canicola and Sejroe were isolated from the mongoose only [67]. Another survey was conducted in Hawaii between 1969 and 1973 on 2982 animals of the same species [68] and the following seroprevalences were found: $34.0 \%(419 / 1234)$ positive in $R$. rattus, $61.4 \%(137 / 223)$ in $R$. norvegicus, $17 \cdot 8 \%(166 / 932)$ in $R$. exulans, $43 \cdot 2 \%(41 / 95)$ in M. musculus and $28.8 \%(136 / 473)$ in H. auropunctatus [68]. Cultures of kidneys showed that serogroup Icterohaemorrhagiae was predominant in $R$. norvegicus $(91.4 \%$ of positives, $85 / 93)$, while $58.7 \%(24 / 41)$ of the identified cultures recovered from mice were from serogroup Ballum and $59 \cdot 7 \%$ (43/72) of those recovered from mongooses were from serogroup Sejroe. Serogroups Icterohaemorrhgiae and Ballum were isolated from all rat species and mice, but not from mongooses, while Sejroe was isolated only from mongooses [68].

\section{Marine mammals}

A serological study on the endemic monk seals of Hawaii Monachus schauinslandi (order Carnivora, family Phocidae) showed that leptospirosis was circulating in this population and that monk seals had positive titres against serovars bratislava (Australis), hardjo (Sejroe), icterohaemorrhagiae (Icterohaemorrhagiae) and pomona (Pomona) [69].

\section{Livestock}

Serovars hardjo (Sejroe) and bataviae (Bataviae) were identified by MAT in cattle on Kauai island in 1987 [70].

\section{FRENCH POLYNESIA}

\section{Livestock}

In 1988, Raust [71] published the results of a serological survey showing that $15.5 \%(23 / 148)$ of dairy cattle were seropositive and that the dominant serovar was hardjo (Sejroe) in $43 \%$ of those positive, followed by serovar tarassovi (Tarassovi) in 14\% and serovar sejroe (Sejroe) in $10 \%$. A health control conducted in 1997 in cattle confirmed the results of 1988 [72].

In $1988,32 \%(37 / 115)$ [71] to $39 \%(140 / 360)$ [65] of pigs were seropositive by MAT. Both studies reported icterohaemorrhagiae (Icterohaemorrhagiae) as the most prevalent serovar in this species $(22.6 \%$ of positive pigs for the former, $96 \%$ for the latter). The first study also identified pomona (Pomona, 18\%), bratislava (Australis, 16.7\%), canicola (Canicola, $10 \cdot 8 \%$ ), cynopteri (Cynopteri, $9 \cdot 9 \%$ ) and autumnalis (Autumnalis, $7 \cdot 1 \%$ ) as circulating serovars in pigs [71].

\section{Equines}

Only five horses were tested during the survey of Raust in 1988 [71], and all were seropositive. Serovars pomona (Pomona), australis (Australis) and icterohaemorrhagiae (Icterohaemorrhagiae) were identified in this species.

\section{LA RÉUNION}

\section{Micromammals}

In 2007, a serological survey on tenrecs Tenrec ecaudatus (order Lipotyphla, family Tenrecidae) showed a seroprevalence of $92 \%(34 / 37)$ in this species with all sera predominantly reacting against serogroup Icterohaemorrhagiae [73].

\section{Domestic carnivores}

Two serosurveys conducted in a dog pound in 1977-1979 [74] and 1978-1983 [75] showed that 40\% (58/142 and 60/150, respectively) of the stray dogs were seropositive by MAT. In the former study, serogroups Canicola and Icterohaemorrhagiae were found in $69 \%(40 / 58)$ and $26 \%(15 / 58)$, respectively, of the seropositive dogs [74] while in the latter study $16 \%$ of those seropositive had antibodies against Icterohaemorrhagiae [75]. 


\section{Livestock}

In 1978-1979, two simultaneous serological studies showed similar results with $29 \%(452 / 1582)$ [76] and $32 \%(337 / 1063)$ [74] of cattle having a positive serological titre. Serogroups Hebdomadis and Sejroe each represented $25 \%$ of the seropositive reactions [74, 76], serogroup Icterohaemorrhagiae accounted for $12-13 \%$ [75, 77], Pomona $12 \%$ [76], Autumnalis $10-12 \%$ [74, 76], Ballum 5\% [76], Australis, Bataviae and Grippotyphosa $4.5 \%$ each, and Canicola $0.5 \%$ [76]. In La Réunion, serogroups Sejroe and Hebdomadis were recognized as a major cause of abortion in dairy cattle [77].

A sampling conducted in 1979 at a slaughter-house revealed a limited circulation of leptospires in swine, with $5 \%(3 / 57)$ of pigs seropositive and circulation of serogroups Autumnalis and Hebdomadis [74]. Currently, field data indicate a high seroprevalence rate in reproduction swine: a serological follow-up of 13 pig farms between 2001 and 2008 showed that each year $6-29 \%$ of the tested sera were positive (Dr P. André, personal communication).

\section{Equines}

At the end of the 1970s, there were four riding schools in La Réunion, accounting for about 150 horses. In this equine population, 10-20 cases of leptospirosis occurred throughout the year [77]. In 1979, two serological surveys $[74,76]$ revealed that $69 \%(100 / 145)$ to $71 \%(121 / 171)$ of the horses were seropositive. Eleven different serogroups were serologically identified in horses and the predominant serogroup was Autumnalis (30-34\% of positive reactions), while Icterohaemorrhagiae was found in $14-18 \%$ of positive animals [74, 76]. In 1983, Mollaret et al. [75] confirmed that $12 \%$ of horses were serologically reactive against serogroup Icterohaemorrhagiae. Moutou [74] pointed out that the prevailing serogroup differed among the riding school of origin: Icterohaemorrhagiae in the riding school of St-Denis, Australis in the riding schools of St-Gilles and Tampon, Ballum in horses of Bras Panon. Nevertheless, in 1990, following a clinical outbreak of leptospirosis in the riding school of Tampon, 22 horses were tested. All were seropositive for Icterohaemorrhagiae (Dr A. Michault, personal communication). Thus if leptospirosis is highly prevalent in horses in $\mathrm{La}$ Réunion without systematic clinical expression of the disease, serogroup Icterohaemorrhagiae could be responsible for clinical outbreaks.

\section{MAYOTTE}

\section{Micromammals and wild fauna}

The 19 rats sampled in 1991 were all seronegative by MAT [78].

In the same year, the circulation of serovar hardjo (Sejroe) was shown in two out of ten tenrecs T. ecaudatus and in the only fruit bat Pteropus seychellensis (order Chiroptera, family Pteropodidae) caught. Antibodies against serogroup Pyrogenes and serovar wolffi (Sejroe) were also found in the tenrec, while antibodies against serovar icterohaemorrhagiae (Icterohaemorrhagiae) were found in small Indian civets Viverricula indica (order Carnivora, family Viverridae) [78].

\section{Domestic carnivores}

MAT results showed the circulation of serovar icterohaemorrhagiae (Icterohaemorrhagiae) in dogs [78].

\section{Livestock}

At the beginning of the $1990 \mathrm{~s}$, zebus, goats and dogs were highly infected, with $85 \%(34 / 40), 70 \%(7 / 10)$ and $83 \%(5 / 6)$ seropositive, respectively. In zebus, serovars identified by MAT were canicola (Canicola), grippotyphosa (Grippotyphosa), sejroe (Sejroe), each accounting for $23.5 \%$ of the seropositives, then ballum (Ballum, $11 \cdot 7 \%$ ), Pyrogenes $(8.8 \%$ ), wolffi (Sejroe, 5.8\%) and australis (Australis, 2.9\%). In goats, serovars were icterohaemorrhagiae, wolffi (each accounting for $28.6 \%$ of seropositives), canicola, ballum and grippotyphosa (14.3\% each) [78].

\section{DISCUSSION}

\section{Origin of the serovars}

Introduction of animal species in a region induces introduction of simultaneous pathogens. So, originally, the presence of leptospiral serovars circulating on each island was linked with the history of the human colonization and the shipping importations of animals by the Europeans [20, 28, 79]. Nevertheless, serovars circulating on a colonized island are different from those of the colonizing country. Even if no study has compared mainland and tropical islands, we know that serovars carried by rats, mice and hedgehogs (Erinaceus europaeus) in New Zealand are not the same as those carried by the same species in 
Great Britain, the country from where they were imported during colonization [80]. Thus, the few serogroups of leptospires circulating in animals on an island are specific to the animals which have colonized the island and could maintain themselves in this typical environment. Serovars present on tropical islands are generally circulating worldwide but each island represents a unique ecosystem, the limited panel of serovars found in each insular area is absolutely island specific.

\section{The case of vaccinated animals}

The most commercially available vaccines against leptospirosis are for dogs and are directed against serogroups Icterohaemorrhagiae and Canicola. Consequently, the presence of seropositive domestic dogs [50] and the presence of both these serogroups in high proportions in populations of healthy dogs [60, 61] could be partly explained by the vaccination measures currently practised in the majority of the presented islands. Nevertheless, a study in Trinidad showed that vaccination did not have any significant effect on Leptospira infection as similar prevalence of infections were detected for both vaccinated $(5 \cdot 3 \%)$ and non-vaccinated dogs (7.7\%) [57]. Moreover, Hathaway et al. [80] showed that agglutinins induced by the vaccine disappear within weeks of administration [81]. Consequently, the seropositive dogs detected in the different studies were essentially due to exposure to field serovars of Leptospira sp.

\section{Carrier state and immune response}

In Hawaii the rate of renal infection in $R$. norvegicus, $R$. rattus and $M$. musculus is significantly higher than the serological prevalence in each species [67]. The same observation was reported in the rodent population of Terceira Island (Azores) [9] and in $R$. norvegicus caught in Brazil [7, 38]. Duration of immunity is not known in field rats, but after infection in carrier animals, leptospires are subsequently cleared from all organs except the renal tubules [82]. Thus, in the absence of re-infection, carrier animals may be serologically negative, thus the carrier state may not be detected in MAT-positive animals. In contrast, other studies showed that the serological prevalence in rats is higher than the renal carriage [8]. Consequently, serology is often not clear, as MATnegative bacteriologically proved carriers may be encountered [2].

\section{Diversity of hosts and serovars in insular areas}

In insular areas of volcanic origin like La Réunion, Mayotte, Hawaii, Martinique, Guadeloupe and French Polynesia, the mammalian diversity is generally poor and leptospires have a limited choice in mammalian hosts compared to the larger choice offered by continental countries like Guyana [83], Peru [84], Brazil [85], or larger islands, e.g. New Zealand [80] or Australia [86]. In consequence, bacteria concentrate themselves in abundant species, susceptible but generally non-sensitive, living most frequently in an anthropic environment, and which are perfect to play the role of reservoir and spreader of bacteria. On these islands, this role is played most frequently by alien species, e.g. rats and mice, or even mongooses and dogs.

Almost all knowledge on leptospirosis is related to infection in mammals but the finding of Leptospira in amphibians and reptiles $[45,46]$, which live in moist or wet environments, and birds [55], leads to questions about the role of these species, if any, in the carriage and maintenance of foci of leptospirosis.

\section{Comparison with mainland}

The seroprevalence of leptospirosis in animals seems to be higher in small islands than in mainland or larger islands but the number of circulating serovars is lower. In fact, the diversity of serovars in a region may be correlated on the one hand directly with the faunistic diversity of the area (number of potential hosts) and on the other with its environmental diversity [8]. For example, in Australia, which can be considered as the nearest 'mainland' from New Caledonia, the prevalence of leptopsirosis in the dog population is $1.9 \%(18 / 956)$ [87], which is markedly inferior to the prevalence in New Caledonian dogs $(59 \cdot 25 \%)$ [60]. Nevertheless, although only two serovars are described in the New Caledonian canids [60, 61], 11 are found in Australian dogs [87]. An other example can be found in Trinidad which has a greater mammal species diversity (about 100 mammalian species) than the neighbouring island of Grenada (15 mammalian species): 80 isolates of L. interrogans were reported in Trinidad to infect humans, domestic and wild animals, and only 20 were reported in Grenada [88]. The hypothesis is reinforced by the situation in the temperate Azorean islands (North Atlantic ocean) where three serovars are described in the four rodents and insectivorous 
mammal species present, while six serovars are counted among the 21 micromammals in Portugal $[51,89]$.

\section{Adaptation of the serovars to insular ecosystems}

When a serovar is introduced within a new ecosystem, it finds an ecological niche that may be different from the one it uses in its native environment. Indeed, one animal species, living in two different countries/ islands within two different ecosystems, may offer two distinct ecological niches for leptospires [80, 90]. Generally, in a geographical region an equilibrium is established in which there is an 'adaptation' of a serogroup to a reservoir species $[4,74]$. Thus, the Indian mongoose ( $H$. auropunctatus) is considered as a reservoir for serogroups Sejroe, Icterohaemorrhagiae and Canicola in Hawaii [67, 68], serogroup Sejroe in Oahu island [91], serogroups Icterohaemorrhagiae, Sejroe and Australis in Guadeloupe [51, 52], serogroup Canicola in Trinidad [13, 19] and serovars copenhageni (Icterohaemorrhagiae), atchafalaya (Tarassovi) and brasiliensis (Bataviae) in Grenada [19]. Moreover, in La Réunion, Moutou [74] reported that the dominant serogroup identified by serology in horses differed according to the riding school in which the animals lived, i.e. according to the geographical zone of the island.

Lastly, it should be noted that phenomena of speciation by adaptation to a particular host in a small biotope can lead to the appearance of new serovars, e.g. serovar bim (Autumnalis) in dogs on Barbados [48] or atchafalaya (Tarassovi) in Grenadian mongooses [19], or even serovar lanka (Louisiana) in Trinidad [19].

\section{Evolution of seroprevalence}

Few studies report a follow-up of the seroprevalence of leptospirosis in animal species. A survey was conducted between 1959 and 1961 on five species of wild mammals in Hawaii [67] and another survey on the same species was conducted between 1969 and 1973 [68] (see earlier results): comparison between the two studies shows that (i) serogroups of Leptospira sp. isolated by culture in each animal species were the same but the relative distribution of the serovars per species was different and (ii) the serogroup Sejroe was emergent in the mongoose. Furthermore, the respective densities of the rodents and mongooses have changed in Hawaii, with an increase of the populations of $R$. rattus, $R$. exulans and mongooses, while the populations of $R$. norvegicus and mice decreased. In consequence, although in the 1960 s $R$. norvegicus and the mouse were the main reservoirs of leptospires in Hawaii, in 1973 R. rattus represented the main bacterial reservoir. Therefore, the epidemiology of the disease had changed in Hawaii, switching from a peridomestic animal reservoir ( $R$. norvegicus and mouse) to a more rural reservoir ( $R$. rattus and mongoose) [68].

Different examples show that the seroprevalence of leptospirosis in one species seems to be quite stable over time. In 1971-1972 and in 1983, two serosurveys proved that the seroprevalence assessed by MAT in mongooses in Grenada did not evolve over 10 years with a prevalence of $35 \%$ [13] and $36 \%$, respectively [19]. Moreover, prevalence of antibodies did not change much in Trinidadian mongooses over 6 years, with $33 \cdot 3-51 \cdot 1 \%$ seropositive in 1976 [13], whereas in 1983 , $48 \%$ of the mongooses sampled were seropositive [19]. In La Réunion two serosurveys conducted in the same dog pound at two distinct periods (1977-1979 [74] and 1978-1983 [75]) showed that $40 \%(58 / 142$ and $60 / 150$, respectively) of the stray dogs were seropositive by MAT. Similarly for French Polynesia the seroprevalence in cattle did not evolve between 1988 and 1997 [65].

Nevertheless, an exception can be found in the population of pigs in La Réunion in which the seroprevalence seemed to increase significantly over 30 years going from $5 \%$ of pigs seropositive in 1979 to $6-29 \%$ at 7 years follow-up conducted between 2001 and 2008. Three hypothesis can be put forward: (i) the survey of Moutou [74] underestimated the prevalence of the disease in swine, either because of a too small sample size or because the animals sampled were too young; (ii) the disease has greatly evolved in $\mathrm{La}$ Réunion, with a 'burst' occurring during the last 30 years; (iii) changes in the methods of farming, going from small family pig farms to battery industrial breeding farms could have induced an evolution in the prevalence of leptospirosis in pigs. Thus, higher animal density could favour the maintenance and transmission of the disease inside farms, and the gathering of fattening animals born in different reproductive farms, or in a growing farm could favour the spread of the disease between sites. Moreover the seroprevalence and consequences of the disease are different when considering breeding sows or grower animals [92]. 


\section{Meteorological factors}

In tropical regions, high rainfall is the main climatic factor of maintenance of leptospires in the environment and of their transmission to exposed animals and humans [93, 94]. A survey conducted in Hawaii between 1969 and 1973 showed that the seroprevalence rates in rodents and mongooses were higher on the Eastern coast (where rainfall is high) than on the Western part of the island [68]. In North America, a statistical positive correlation was also demonstrated between prevalence of infection in dogs and rainfall [95]. Moreover, in 2002-2003 and 2003-2004 the Caribbean region had two successive years of the El Niño phenomenon, which resulted in an increase in rainfall and probably in a proliferation of rodents which modified the epidemiology of human leptospirosis in Guadeloupe. In consequence, not only was there an increase in the total number of human cases observed in this island, but also the number of cases due to serogroup Ballum, a mouse-associated serogroup [8, 9] increased [96].

Nevertheless, cyclones do not appear to be linked with an increase in the number of human cases in $\mathrm{La}$ Réunion (Dr A. Michault, personal communication), nor in Guadeloupe [96]. It is likely that these intense climatic phenomena are responsible for the leaching of the environmental reservoirs and the destruction of the habitats of the micromammals considered as reservoirs [96].

\section{CONCLUSION}

This paper reviews the current knowledge on animal leptospirosis in small tropical islands and shows that the specificity of the host-serovar relation is greatly dependent of a specific insular ecosystem. However, the interpretation of the serological results and comparison between islands might be hazardous for two main reasons: (i) data are mainly stemmed from seroepidemiological surveys that include a variable number of species and individuals, and (ii) methods of analysis and thresholds of positivity differ between studies.

Nonetheless, leptospirosis appears endemic in the majority of the animal species. If the status of domestic or peri-domestic (rats, mongooses, mice) animals against leptospirosis has been well studied in insular areas, the wild fauna has been investigated less so. The interest of the scientific community in animal leptospirosis in these regions is modest thus far, and available data are often poor, mainly due to the fact that research is concentrated on the human disease. This paper stresses the need for more research in this field and highlights that studies on fauna have to be done at the island scale. Identification of the prevailing serovars and of their animal reservoirs is essential to understand the particular epidemiology of leptospirosis on each island and advise measures of prevention for humans. Furthermore, the economic cost of human and animal leptospirosis in these islands is not negligible [97]. Because molecular tools are more powerful than serology and because they allow the establishment of stronger epidemiological links between strains circulating in animals and those inducing disease in humans, the use of genotyping techniques needs to be incorporated into epidemiological studies of Leptospira sp. in insular areas in order to generate more meaningful and translational data.

\section{ACKNOWLEDGEMENTS}

We are very grateful to Pierre Aubry (Emeritus Professor at the Medicine Faculty of Antananarivo, Madagascar), Margarida Collares-Pereira (Institute of Hygiene and Tropical Medicine, New University of Lisbon, Portugal) and Cyrille Goarant (Pasteur Institute, New Caledonia) for providing several cited papers. We thank François Moutou (AFSSA, Paris), Michel Pascal (INRA, Rennes), Pascale Bourhy (Centre National de Références des Leptospiroses, Pasteur Institute, Paris), Vincent Porphyre (CIRAD, La Réunion) and Paul André (Veterinarian, La Réunion) for their scientific advice, and Hélène Delatte (CIRAD, La Réunion) for support.

Political and population information on countries has been extracted from Wikipedia via the internet and is not necessarily accurate.

\section{DECLARATION OF INTEREST}

None.

\section{REFERENCES}

1. Everard COR. Leptospirosis in the Caribbean. Bulletin of the Pan American Health Organization 1981; 15: 397-399.

2. Faine S, et al. Leptospira and leptospirosis, 2nd edn. Melbourne, Australia: MediSci, 1999, p. 296.

3. Morey RE, et al. Species-specific identification of Leptospiraceae by $16 \mathrm{~S}$ rRNA gene sequencing. Journal of Clinical Microbiology 2006; 44: 3510-3516. 
4. Adler B, de la Peña Moctezuma A. Leptospira and leptospirosis. Veterinary Microbiology 2010; 140: 287-296.

5. Bahaman AR, Ibrahim AL. A short review of animal leptospirosis with special reference to Malaysia. Tropical Biomedicine 1987; 4: 93-99.

6. Levett PN. Leptospirosis. Clinical Microbiology Reviews 2001; 14: 296-326.

7. Pereira MM, Andrade J. Epidemiological aspects of leptospirosis in a slum area in the city of Rio de Janeiro, Brazil. Search for leptospires and specific antibodies in rodents. Transaction of the Royal Society of Tropical Medicine and Hygiene 1988; 82: 768-770.

8. Vanasco NB, et al. Associations between leptospiral infection and seropositivity in rodents and environmental characteristics in Argentina. Preventive Veterinary Medicine 2003; 60: 227-235.

9. Collares-Pereira M, et al. Rodents and Leptospira transmission risk in Terceira island Azores). European Journal of Epidemiology 2000; 16: 1151-1157.

10. Centre National de Référence des leptospires. Rapport annuel d'activité pour l'année 2007. Paris: Institut Pasteur.

11. Everard CO, et al. A twelve-year study of leptospirosis on Barbados. European Journal of Epidemiology 1995; 11: 311-320.

12. Katz AR, et al. Assessment of the clinical presentation and treatment of 353 cases of laboratory-confirmed leptospirosis in Hawaii, 1974-998. Clinical Infectious Diseases 2001 ; 33: 1834-1841.

13. Everard COR, Green AE. Leptospirosis in Trinidad and Grenada, with special reference to the mongoose. Transaction of the Royal Society of Tropical Medicine and Hygiene 1976; 70: 57-61.

14. Gargominy O, et al. Consequences for biodiversity of plant and animal species introductions in New Caledonia [in French]. Revue d'Ecologie (Terre et Vie) 1996; 51: 375-402.

15. Official Website of the Association for Preservation and Rehabilitation of Wildlife Caribbean [in French] (http:// www.faune-guadeloupe.com/3-categorie-755619.html). Accessed 17 September 2009.

16. Global Invasive Species Database (http://www.issg.org/ database). Accessed 10 November 2009.

17. World Wildlife Fund Full Report. Trinidad and Tobago moist forests (http://www.worldwildlife.org/wildworld/ profiles/terrestrial/nt/nt0171_full.html). Accessed 5 October 2009.

18. Long JL. Introduced Mammals of the World. Their History, Distribution and Influence. Victoria, Australia: CSIRO Publishing, 2003, p. 612.

19. Everard CO, et al. Leptospires in wildlife from Trinidad and Grenada. Journal of Wildlife Diseases 1983; 19: 192-199.

20. Lorvelec O, Pascal M, Pavis C. Checklist and status of the French West Indies mammal species (except Chiroptera and Cetacea) [in French]. Petit-Bourg, Guadeloupe: Association for Study and Protection of Vertebrates and Plants of the Lesser Antilles, 2001.

21. Matthias MA, Levett PN. Leptospiral carriage by mice and mongooses on the island of Barbados. West Indian Medical Journal 2002; 51: 10-13.
22. Soubeyran Y. Exotic invasive species in French overseas collectivities. Inventory and recommendations. Synthesis by collectivity [in French]. Paris, France: IUCN French Committee, 2008, p. 141.

23. Stone CP, et al. Non-native land vertebrates. In: Stone CP, Stone DB, eds. Conservation Biology in Hawaii. Honolulu, Hawaii: University of Hawaii Press, 1988, p. 280 .

24. Wikramanayake ED, Dinerstein E, Loucks CJ. Terrestrial Ecoregions of the Ondo-Pacific. A Conservation Assessement. Illustrated edn. Island Press, 2001, p. 643.

25. MacArthur RH, Wilson EO. The Theory of Island Biogeography. Princetown Landmarks in Biology. Princeton: Princeton University Press, 2001, p. 203.

26. Lorvelec $\mathbf{O}$, et al. The non-flying terrestrial mammals of the French West Indies, and the recent introduction of a squirrel [in French]. Revue d'Ecologie (Terre et Vie) 2007; 62: 295-314.

27. Courchamp F, Chapuis JL, Pascal M. Mammals invaders on islands: impact, control and control impact. Biological Reviews 2003; 78: 347-383.

28. Howald $\mathbf{G}$, et al. Invasive rodent eradication on islands. Conservation Biology 2007; 21 : 1258-1268.

29. Pascal M, et al. Vertebrate species in New Caledonia: invasions and extinctions. In: Beauvais M-L, Coléno A, Jourdan A, eds. Invasive Species in New Caledonian Archipelago [in French]. IRD Éditions, Paris, 2006, pp. 111-162.

30. O'Connell M. Marmosa robinsoni. Mammalian Species 1983; 203: 1-6.

31. Proceedings of the fourth meeting of Caribbean foresters. In: Wildlife Management in the Caribbean Islands. Institute of Tropical Forestry and the Caribbean National Forest, Rio Piedras, Puerto Rico, 1989.

32. Germano JM, et al. Herpetofaunal communities in Grenada: a comparison of altered sites, with an annoted checklist of Grenadian amphibians and reptiles. Caribbean Journal of Science 2003; 39: 68-76.

33. ICZN (International Commission on Zoological Nomenclature). Opinion 2027 (Case 3010). Usage of 17 specific names based on wild species which are predated by or contemporary with those based on domestic animals (Lepidoptera, Osteichthyes, Mammalia): conserved. Bulletin of Zoological Nomenclature 2003; 60: 81-84.

34. World Health Organization. Human Leptospirosis: Guidance for Diagnosis, Surveillance and Control. Malta: World Health Organization, 2003, p. 122.

35. Kazami A, et al. Serological survey of leptospirosis in sows with premature birth and stillbirth in Chiba and Gunma prefectures of Japan. Journal of Veterinary and Medical Science 2002; 64: 735-737.

36. Dassanayake D, et al. Evaluation of surveillance case definition in the diagnosis of leptospirosis, using the Microscopic Agglutination Test: a validation study. BMC Infectious Diseases 2009; 9: 48.

37. Lilenbaum W, et al. Identification of Leptospira spp. carriers among seroreactive goats and sheep by polymerase chain reaction. Research in Veterinary Science (in press). 
38. Tucunduva de Faria M, et al. Carriage of Leptospira interrogans among domestic rats from an urban setting highly endemic for leptospirosis in Brazil. Acta Tropica 2008; 108: 1-5.

39. Kuriakose M, et al. Leptospirosis in a midland rural area of Kerala state. Indian Journal of Medical Research 2008; 128: 307-312.

40. Wuthiekanun V, et al. Optimization of culture of Leptospira from humans with leptospirosis. Journal of Clinical Microbiology 2007; 45: 1363-1365.

41. Taylor KD, Turner LH, Everard JD. Leptospires in Rattus spp. on Barbados. Journal of Tropical Medicine and Hygiene 1991; 94: 102-103.

42. Levett PN, et al. Surveillance of leptospiral carriage by feral rats in Barbados. West Indian Medical Journal 1998; 47: 15-17.

43. Baulu J, Everard CO, Everard JD. Leptospires in vervet monkeys (Cercopithecus aethiops Sabaeus) on Barbados. Journal of Wildlife Diseases 1987; 23: 60-66.

44. Everard COR, et al. Leptospires in the marine toad (Bufo marinus) on Barbados. Journal of Wildlife Diseases 1988; 24: 334-338.

45. Gravekamp C, et al. Leptospires isolated from toads and frogs on the island of Barbados. Zentralblatt für Bakteriologie 1991; 275: 403-411.

46. Everard CO, et al. Leptospires in the whistling frog (Eleutherodactylus johnstonei) on Barbados. Journal of Tropical Medicine and Hygiene 1990; 93: 140-145.

47. Weekes CC, Everard COR, Levett PN. Seroepidemiology of canine leptospirosis on the island of Barbados. Veterinary Microbiology 1997; 57: 215-222.

48. Jones CJ, et al. Bim, a new serovar of Leptospira interrogans isolated from a dog in Barbados. Journal of Clinical Microbiology 1984; 19: 946.

49. Levett PN, Whittington CU, Camus E. Serological survey of leptospirosis in livestock animals in the lesser Antilles. Annals of the New York Academy of Sciences 1996; 791: 369-377.

50. André-Fontaine G. Animal leptospirosis [in French]. Bulletin Epidémiologique de l'Afssa 2004; 12: 1-3.

51. Michel V. Study of the role of different wild species and of their environment on the epidemiology of zoonotic leptospirosis [in French] (thesis). Lyon: Université Claude Bernard, 2001, 251 pp.

52. Michel V, Branger C, Andre-Fontaine G. Epidemiology of leptospirosis. Revista Cubana de Medicina Tropical 2002; 54: 7-10.

53. Tissot D, Mailloux M, Corroller YL. Serological study on bovine leptospirosis in Guadeloupe. Bulletin de la Société de Pathologie Exotique Filiales 1975; 68: 420-425.

54. Levillain A. La leptospirose aux Antilles. CIRE AntillesGuyane, 2001.

55. Everard COR, et al. Serological studies on leptospirosis in livestock and chickens from Grenada and Trinidad. Transaction of the Royal Society of Tropical Medicine and Hygiene 1985; 79: 859-864.

56. Everard CO, et al. Leptospirosis in dogs and cats on the island of Trinidad: West Indies. International Journal of Zoonoses 1979; 6: 33-40.
57. Adesiyun AA, et al. Sero-epidemiology of canine leptospirosis in Trinidad: serovars, implications for vaccination and public health. Journal of Veterinary Medicine B 2006; 53: 91-99.

58. Adesiyun AA, et al. Leptospirosis in water buffalo (Bubalus bubalis) in Trinidad. Veterinarski Arhiv 2009; 79: 77-86.

59. Brethes B, et al. Epidemiological study of leptospirosis in New Caledonia [in French]. Bulletin de la Société de Pathologie Exotique 1988; 81: 189-197.

60. Brethes B, et al. Leptospirosis and environment. Study in the two most important focuses of New Caledonia [in French]. Revue d'Epidémiologie et de Santé Publique 1988; 36: 436-442.

61. Centre National de Référence des Leptospires. Rapport annuel d'activité 1999. Paris: Institut Pasteur.

62. Thevenon JG, et al. Epidemiological study of bovine leptospirosis in New-Caledonia [in French]. Recueil de Médecine Vétérinaire 1990; 166: 903-909.

63. Domenech J, Lechapt M. Animal leptospirosis: prevalence in the South Pacific [in French]. Revue d'Elevage et de Médecine Vétérinaire de Nouvelle-Calédonie 1983; 2: 1-8.

64. Centre National de Référence des Leptospires. Rapport annuel d'activité 1996. Paris: Institut Pasteur.

65. Centre National de Référence des Leptospires. Rapport annuel d'activité 1998. Paris: Institut Pasteur.

66. Wallace GD, Gross B, Lee R. Leptospirosis survey of small mammals on the island of Hawaii. In: 10th Pacific Scientific Congress, Honolulu, 1961.

67. Minette HP. Leptospirosis in rodents and mongooses on the Island of Hawaii. American Journal of Tropical Medicine and Hygiene 1964; 13: 826-832.

68. Shimizu MM. Environmental and biological determinants for the prevalence of leptospirosis among wild small mammal hosts, island of Hawaii. International Journal of Zoonoses 1984; 11: 173-188.

69. Aguirre AA, et al. Infectious disease monitoring of the endangered hawaiian monk seal. Journal of Wildlife Diseases 2007; 43: 229-241.

70. Katz AR, Manea SJ, Sasaki DM. Leptospirosis on Kauai: investigation of a common source waterborne outbreak. American Journal of Public Health 1991; 81: 1310-1312.

71. Raust P. Animal leptospirosis in French Polynesia. Preliminary serological investigations [in French]. Revue d'Elevage et de Médecine Vétérinaire de NouvelleCalédonie 1988; 12: 15-19.

72. Centre National de Référence des Leptospires. Rapport annuel d'activité 1997. Paris: Institut Pasteur.

73. Sigaud M, et al. Tailless tenrec (Tenrec ecaudatus): natural maintenance host of leptospires? [in French]. Bulletin de la Société de Pathologies Exotiques 2009; 102: 19-20.

74. Moutou F. Survey on the Murinae fauna in La Reunion French department. Rapport DDASS, 1980.

75. Mollaret HH, Mailloux M, Debarbat F. Leptospiroses in the island of Reunion. III. Epidemiological study [in French]. Bulletin de la Société de Pathologie Exotique 1983; 76: 744-749. 
76. Debarbat F, Mollaret HH, Mailloux M. Leptospiroses in the island of Reunion. II. Animal leptospiroses [in French]. Bulletin de la Société de Pathologie Exotique 1983; 76: 736-743.

77. Gares H. Study of infertility risk factors in Reunion island dairy herds [in French] (thesis). Toulouse: Université Paul Sabatier, 2003, 103 pp.

78. Charton A. Contribution to the epidemiological study of leptospirosis. The case of Mayotte [in French] (thesis). Lyon: Ecole Nationale Vétérinaire de Lyon, 1992, $101 \mathrm{pp}$.

79. Matisoo-Smith E, et al. Patterns of prehistoric human mobility in Polynesia indicated by mtDNA from the Pacific rat. Proceedings of the National Academy of Sciences USA 1998; 95: 15145-15150.

80. Hathaway SC, Blackmore DK, Marshall RB. Leptospirosis in free-living species in New Zealand. Journal of Wildlife Diseases 1981; 17: 489-496.

81. Klaasen HLBM, et al. Duration of immunity in dogs vaccinated against leptospirosis with a bivalent inactivated vaccine. Veterinary Microbiology 2003; 95: 121-132.

82. Athanazio DA, et al. Rattus norvegicus as a model for persistent renal colonization by pathogenic Leptospira interrogans. Acta Tropica 2008; 105: 176-180.

83. Matthias MA, et al. Diversity of bat-associated Leptospira in the Peruvian Amazon inferred by bayesian phylogenetic analysis of $16 \mathrm{~S}$ ribosomal DNA sequences. American Journal of Tropical Medicine and Hygiene 2005; 73: 964-974.

84. Bunnel JE, et al. Detection of pathogenic Leptospira spp. infections among mammals captured in the Peruvian Amazon basin region. American Journal of Tropical Medicine and Hygiene 2000; 63: 255-258.

85. Lilenbaum W, et al. Leptospirosis antibodies in mammals from Rio de Janeiro zoo, Brazil. Research in Veterinary Science 2002; 73: 319-321.

86. Milner AR, et al. The prevalence of anti-leptospiral agglutinins in sera of wildlife in southeastern Australia. Journal of Wildlife Diseases 1981; 17: 197-202.
87. Zwijnenberg RJG, et al. Cross-sectional study of canine leptospirosis in animal shelter populations in mainland Australia. Australian Veterinary Journal 2008; 86: 317-323.

88. Everard CO, et al. Pathogenic leptospira isolates from the Caribbean Islands of Trinidad, Grenada and St. Vincent. International Journal of Zoonoses 1980; 7 : 90-100.

89. Collares-Pereira M, et al. First epidemiological data on pathogenic leptospires isolated on the Azorean islands. European Journal of Epidemiology 1997; 13: 435-441.

90. Martiny JBH, et al. Microbial biogeography: putting microorganisms on the map. Nature Reviews Microbiology 2006; 4: 102-112.

91. Higa HH, Fujinaka IT. Prevalence of rodent and mongoose leptospirosis on the island of Oahu. Public Health Reports 1976; 91 : 171-177.

92. Boqvist $\mathbf{S}$, et al. Leptospira in slaughtered fattening pigs in southern Vietnam: presence of the bacteria in the kidneys and association with morphological findings. Veterinary Microbiology 2003; 93: 361-368.

93. Yanagihara Y, et al. Current status of leptospirosis in Japan and Philippines. Comparative Immunology, Microbiology and Infectious Diseases 2007; 30: 399-413.

94. Tassinari WS, et al. Detection and modelling of case clusters for urban leptospirosis. Tropical Medicine and International Health 2008; 13: 503-512.

95. Ward MP. Seasonnality of canine leptospirosis in the United States and Canada and its association with rainfall. Preventive Veterinary Medicine 2002; 56: 203-213.

96. Hermann Storck C, et al. Changes in epidemiology of leptospirosis in 2003-2004, a two El Nino southern oscillation period, Guadeloupe archipelago, French West Indies. Epidemiology and Infection 2008; 136: 1407-1415.

97. Goarant C, et al. Outbreak of leptospirosis in New Caledonia: diagnosis issues and burden of disease. Tropical Medicine and International Health 2009; 14: 1-4. 